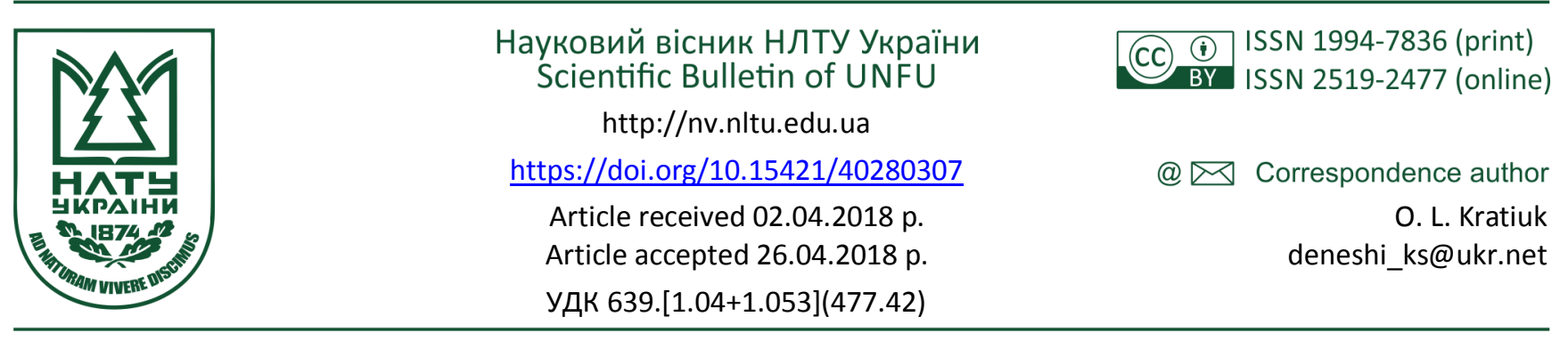

о. Л. Кратюк

Житомирський національний агроекологічний університет, м. Житомир, Україна

\title{
ВИДОВИЙ СКЛАД ТА ДИНАМІКА ЧИСЕЛЬНОСТI РАТИЧНИХ ARTIODACTYLA У ВОЛЬЕРАХ НА ТЕРИТОРІЇ ЖИТОМИРСЬКОЇ ОБЛАСТІ
}

Досліджено видовий склад та динаміку чисельності ратичних тварин у вольєрах на території Житомирської області. Площа вольєрів регіону становить 941,7 га. На 2004 р. на території області існувало 4 вольєри загальною площею 374,2 га. Упродовж 2005-2009 рр. площа вольєрів змінювалася від 117,2 га у 2005 р. до 178,2 га у 2009 р., у 2011 р. вона вже становила 576,7 га, а у 2016 р. - 715,2 га. У вольєрах Житомирської обл. утримують Cervus nippon, Cervus elaphus, Sus scrofa, Capreolus capreolus, Dama dama, Ovis ammon загальною чисельністю 561 особина, яка за період 2004-2017 рр. зросла у 5 разів. На початку XXI ст. на території області існувало 4 вольєри, у яких утримували 46 особин Cervus nippon та 75 особин Sus scrofa. До 2011 р. у вольєрах регіону утримували виключно ці види. У 2013 р. більше половини всього поголів'я (52,4 \%) становила Sus scrofa, то за два роки - у 2016 р. - іï частка становила вже 40,0 \%, а на початку 2018 р. - тільки 20,0 \%. Найстійкішою у господарствах регіону залишається популяція Cervus nippon, чисельність якого змінюється в межах 40-56 особин. Встановлено, що зміна чисельності Sus scrofa за роками дуже істотна: від 15 особин (2005-2007 рр.) до 185 (2014 р.). Користувачі дедалі частіше надають перевагу Cervus elaphus, чисельність якого у вольєрах за останні роки зросла до 166 особин. Упродовж 2012-2017 pр. чисельність Ovis ammon, Capreolus capreolus та Dama dama у господарствах області поступово зростає, як зростає і кількість самих господарств, де їх утримують.

Ключові слова: мисливське господарство; напіввільне утримання; Sus scrofa; Cervus elaphus; Cervus nippon; Dama dama.

Вступ. Процеси взаємодії диких тварин, навколишнього середовища та діяльності людини постійно ускладнюються. Зростання чисельності та щільності тварин в умовах фрагментації природних стацій існування неодмінно призводить до негативного впливу на сільське та лісове господарство (Apollonio et al., 2017), a також до зміни поведінкових стереотипів окремих популяцій, що може бути одним із чинників, які тільки підсилюють стрімку експансію окремих видів ратичних в урбанізовані регіони Свропи (Podgórski et al., 2013).

На тлі інтенсивного розвитку мисливського господарства у більшості країн Свропи (Khoietskyi \& Pokhali$\mathrm{uk}, 2014)$ ратичні в урбанізованих ландшафтах знаходяться під різними джерелами антропогенного тиску, зокрема полювання, як частини скоординованого управління тваринним світом, та браконьєрства, що $є$ справжньою загрозою не тільки для зникаючих, а й для звичайних видів тварин (Sönnichsen et al., 2017). Окрім цього, дедалі очевидніше, що полювання має ширший діапазон ефектів, ніж звичайне зменшення щільності ратичних (Mysterud, 2014). Це спонукає використовувати щоразу нові й нові підходи до управління популяціями ратичних тварин, як відновлюваного ресурсу, які базуються на основі досягнень сучасної екологічної науки, проте на теренах пострадянських країн вони залишаються незмінними протягом останніх 50 років (Apollonio et al., 2017).
Незважаючи на те, що найбільш поширеною формою використання ресурсів ратичних залишається полювання, наразі значного поширення набуває їх розведення в умовах напіввільного утримання, де вони живляться переважно природними кормами, але не мають можливості переміщуватися за межі ізольованої ділянки мисливських угідь (Kaminetskyi, Babich \& Smahol, 2011). Розведення тварин на обмеженій території дає можливість більш досконалого контролю за популяцією, що веде до значного зростання чисельності та якості поголів'я. Особливо це актуально для невеликих мисливських господарств, яких переважна більшість, де через обмеженість площі та придатних до проживання стацій дуже важко сформувати здорову, повноцінну популяцію.

Основними видами господарювання для більшості користувачів мисливських угідь Житомирської області $€$ ратичні тварини, а тому збільшення чисельності та урізноманітнення їх видового складу шляхом розведення у напіввільних умовах є досить актуальним.

Мета роботи. З'ясувати видовий склад та динаміку чисельності ратичних тварин у вольєрах на території Житомирської області.

Матеріали та методи дослідження. Характеристику популяцій ратичних тварин у вольєрах Житомирської області здійснено на основі матеріалів Державної служби статистики України, Державного агентства лі-

Інформація про автора:

Кратюк Олександр Леонідович, канд. біол. наук, доцент, кафедра експлуатації лісових ресурсів. Email: deneshi_ks@ukr.net; https://orcid.org/0000-0002-2661-8074

Цитування за ДСтУ: Кратюк О. Л. Видовий склад та динаміка чисельності ратичних Artiodactyla у вольєрах на території Житомирської області. Науковий вісник Нлту України. 2018, т. 28, № 3. С. 34-37.

Citation APA: Kratiuk, O. L. (2018). Species Composition and Number Dynamics of Artiodactyla Ungulates in Enclosures in the Territory of Zhytomyr Region. Scientific Bulletin of UNFU, 28(3), 34-37. https://doi.org/10.15421/40280307 
сових ресурсів України, а також проектів організації і розвитку мисливського господарства користувачів мисливських угідь Житомирської області.

Результати дослідження та їх обговорення. Мисливське господарство в Житомирській обл. веде 91 користувач. Загальна площа закріплених мисливських угідь області становить 2131875 га, зокрема: лісових 887553 га, польових - 1131900 га, водно-болотних 112422 га. За офіційною статистикою, на 01.03.2018 p. на території Житомирської обл. вольєри функціонують в 11 мисливських господарствах різних форм власності. Згідно 3 лісомисливським районуванням у межах Польської зони функціонує 8 вольєрів, а в Лісостеповій частині області - 3 вольєри. За призначенням вольєри демонстраційні, для тимчасового утримання та розведення мисливських тварин. Площі вольєрів різні - від одного-двох гектарів до сотень.

Наразі загальна площа вольєрів становить 941,7 га (рис. 1). Упродовж 2004-2017 рр. зміна площі вольєрів, згідно з формою державної статистичної звітності 2-ТП "Мисливство", відбувалася стрибкоподібно. Зазначений період можна розділити на кілька етапів, а саме: перший - до 2005 р., другий - 2005-2010 pp., третій 2011-2016 pp. і четвертий - з 2017 р. На 2004 р. на території області існувало 4 вольєри в таких господарствах: ДП "Баранівське ЛМГ" (56,2 га), ДП "Радомишльське ЛМГ" (61,0 га), СФГ "Земля Полісся" (228,0 га) та МГ "В'юнки" (29,0 га). Їх загальна площа становила 374,2 га. У другий період площа вольєрів, за статистичними даними, різко зменшилася, оскільки вольєри СФГ "Земля Полісся" та МГ "В'юнки" не потрапили до статистичної звітності у 2005 р. та наступні роки. Тільки у 2017 р. вольєр СФГ "Земля Полісся" з'явиться у статистичній інформації та приведе до різкого зростання площі вольєрів (четвертий період). Протягом 2005-2009 рр. площа вольєрів змінювалася від 117,2 га у 2005 р. до 178,2 га у 2009 р. Третій період примітний тим, що у 2011 р. було створено вольєр площею 500 га у ТОВ "Камія Плюс". Це найбільший вольер на території Житомирської області. Упродовж 2011-2016 рр. в області тривало поступове зростання площі вольєрів головним чином за рахунок приватних мисливських господарств. У 2011 р. площа вольєрів становила 576,7 га, а у 2016 р. - 715,2 га. Як уже зазначали, що не всі наявні в області вольєри потрапляють до офіційної статистики. Такі вольєри переважно розміщені на території приватних мисливських господарств.

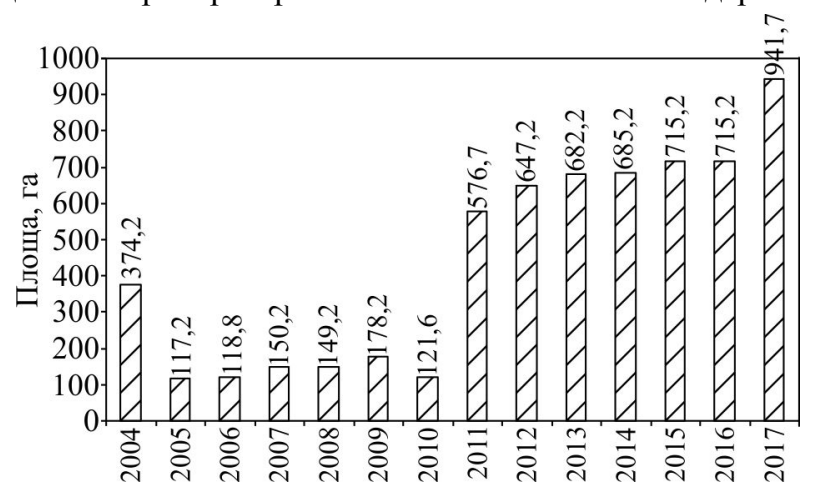

Рис. 1. Динаміка площі вольєрів на території Житомирської області

За останні роки чисельність тварин, яких утримують у вольєрах, поступово зростає (рис. 2). У 2017 р. основне поголів'я ратичних становило 561 особину. Порівняно 32004 р., чисельність тварин зросла майже у 5 разів.

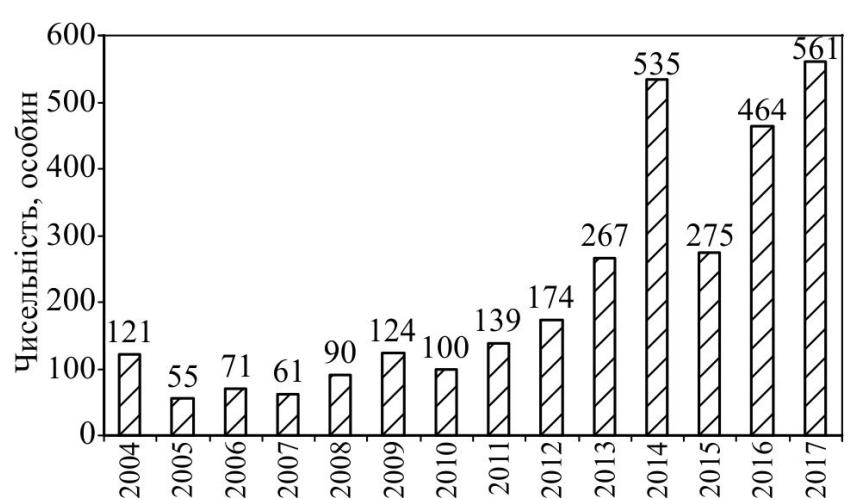

Рис. 2. Динаміка чисельності основного поголів'я ратичних тварин у вольєрах на території Житомирської області

На території України об'єктами вольєрного розведення серед ратичних є свиня дика (Sus scrofa Linnaeus, 1758), козуля європейська (Capreolus capreolus Linnaeus, 1758), олень благородний (Cervus elaphus Linnaeus, 1758), олень плямистий (Cervus nippon Temminck, 1838), лань (Dama dama Linnaeus, 1758), муфлон європейський (Ovis ammon Linnaeus, 1758), зубр (Bison bonasus Linnaeus, 1758) (Yevtushevskyi, 2009, 2012; Smagol \& Gavris, 2013).

Видовий склад ратичних тварин, яких утримують у напіввільних умовах на території Житомирської обл., досить широкий - Cervus nippon, Cervus elaphus, Sus scrofa, Capreolus capreolus, Dama dama, Ovis ammon. На початку XXI ст. на території області у 4 вольєрах утримували 46 особин Cervus nippon та 75 особин Sus scrofa (рис. 3). До 2011 р. у вольєрах регіону були тільки Cervus nippon та Sus scrofa. Невдалою виявилася спроба утримувати Dama dama у ДП "Малинське ЛГ". Тут у вольєрі площею 28,0 га протягом 2007-2009 рр. утримували 6 особин.

З 2011 р. починається поступове збагачення видового складу ратичних у вольєрах. Це стало можливим завдяки діяльності ТОВ "Камія Плюс", до якого було завезено Cervus elaphus, а згодом Ovis ammon та Dama dama. Нині у вольєрі господарства, окрім зазначених видів, є ще Capreolus capreolus та Sus scrofa. Таке спільне утримання призводить до погіршення загального стану угідь. Співвідношення видів у вольєрах наразі вирівнюється. Якщо у 2013 р. більше половини всього поголів'я (52,4 \%) становила Sus scrofa, то за два роки - у 2016 р. - пї частка становила вже 40,0 \% (Kratiuk, 2017), а на початку 2018 р. - тільки 20,0\%.

Найбільш стійкою і прогнозованою у господарствах регіону залишається популяція Cervus nippon (рис. 4). Зміни чисельності виду незначні. Упродовж останніх років чисельність виду змінюється в діапазоні 4056 особин основного поголів'я.

Найнепередбачуванішою нині залишається популяція Sus scrofa. Це зумовлено непоодинокими випадками захворювання на африканську чуму свиней. Зміна чисельності за роками дуже істотна: від 15 особин (20052007 рр.) до 185 ос. (2014 р.). Це пов'язано певною мірою і 3 адміністративними заходами щодо елімінації виду. Користувачі поступово відмовляються утримувати проблемний вид і дедалі частіше надають перевагу Cervus elaphus, чисельність якого у вольєрах за останні роки зросла до 166 особин. Власники час від часу проводять випуски Cervus elaphus в угіддя, чим і зумовлено зменшення кількості тварин у вольєрах у певні роки. 


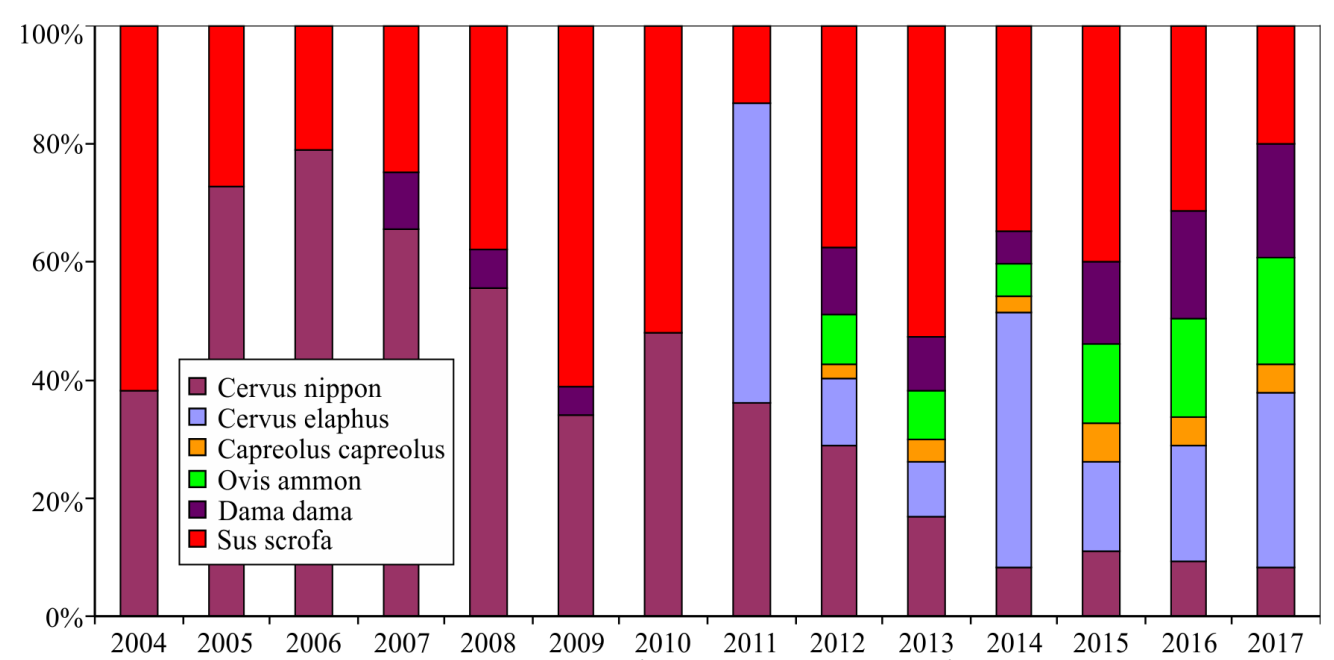

Рис. 3. Співвідношення ратичних тварин у вольєрах на території Житомирської області

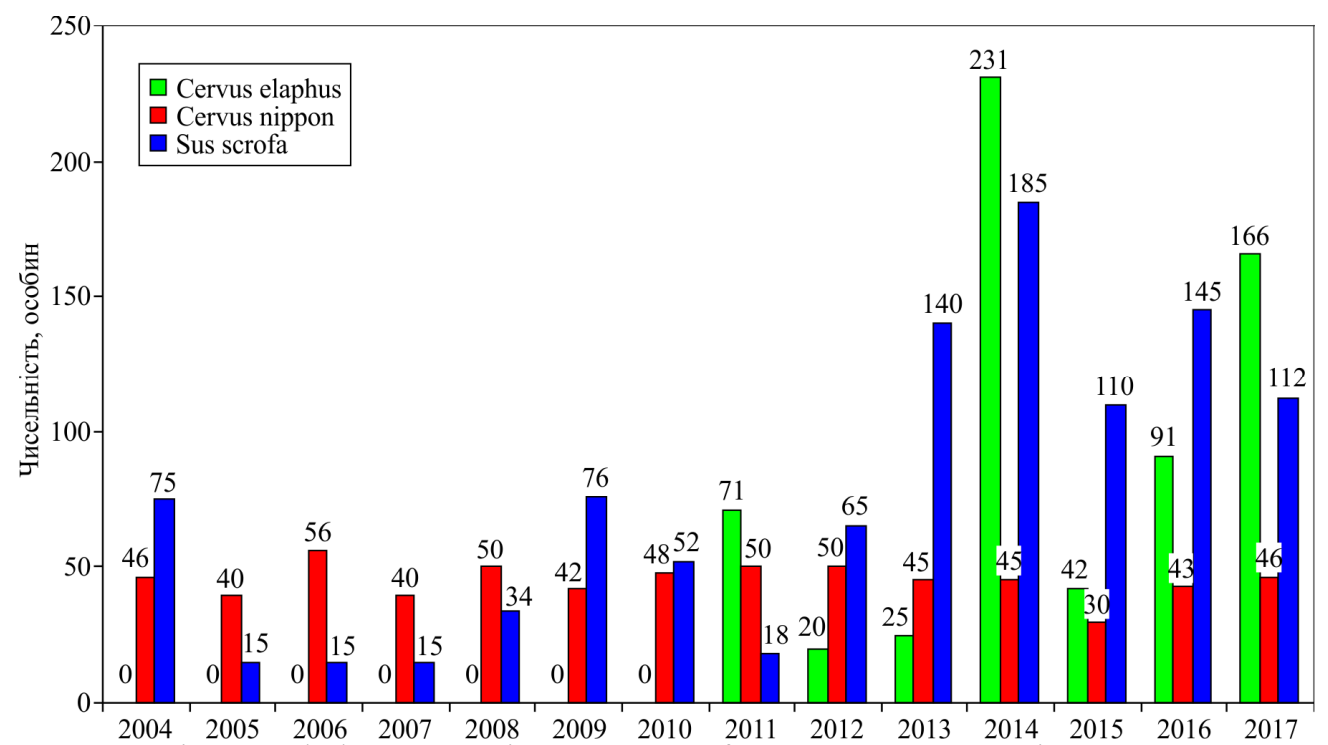

Рис. 4. Динаміка чисельності Cervus elaphus, Cervus nippon та Sus scrofa у вольєрах на території Житомирської області

Досить перспективними для напіввільного утримання є Ovis ammon, Capreolus capreolus та Dama dama. В останні роки їх чисельність у господарствах області поступово зростає, як зростає і кількість самих господарств, де їх утримують (рис. 5). До 2016 р. цих тварин утримували тільки у ТОВ "Камія Плюс", а згодом - у ТОВ МК "Хантер" та ТОВ УТМР. У межах вольєрів їх чисельність зростає шляхом природного приросту.

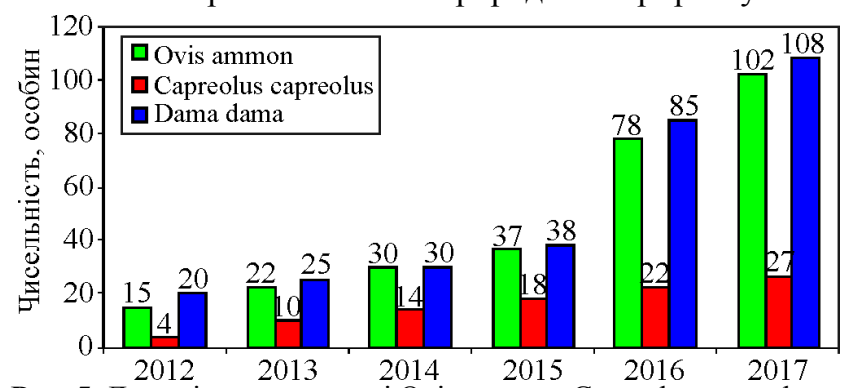

Рис. 5. Динаміка чисельності Ovis ammon, Capreolus capreolus та Dama dama у вольєрах на території Житомирської області

Висновки. Актуальність створення вольєрів щороку зростає. Наразі відбувається переосмислення місця і ролі вольєрів у сучасному мисливському господарстві. Проведений аналіз засвідчує безсистемний підхід до ведення вольєрного господарства на більшості підприємств, незважаючи на інтенсивне проведення біотехнічних заходів. Власники вольєрів подекуди чітко не усвідомлюють можливі напрями розвитку. Незважаючи на це, мисливські господарства Житомирської обл. мають значний потенціал у розвитку вольєрного господарства, про що свідчить збільшення кількості вольєрів, їх площі, чисельності тварин, урізноманітнення видового складу.

\section{Перелік використаних джерел}

Apollonio, M., Belkin, V. V, Borkowski, J., Borodin, O. I., Borowik, T., Francesca Cagnacci, F., et al. (2017). Challenges and sciencebased implications for modern management and conservation of European ungulate populations. Mammal Research, 62, 209-217. https://doi.org/10.1007/s13364-017-0321-5

Kaminetskyi, V. K., Babich, O. H., \& Smahol, V. M. (2011). Ekolohichni ta hospodarski aspekty napivvilnoho rozvedennia dykykh kopytnykh (na prykladi spetsializovanykh pidpryiemstv Derzhavnoho upravlinnia spravamy Prezydenta Ukrainy). Kyiv: ZAT "Myronivska drukarnia". [In Ukrainian].

Khoietskyi, P. B., \& Pokhaliuk, O. M. (2014). Myslyvske hospodarstvo krain Yevropy. [World experience of captive hunting game management]. Scientific Bulletin of UNFU, 24(8), 42-52. [In Ukrainian].

Kratiuk, O. L. (2017). Kharakterystyka voliernoho hospodarstva Zhytomyrskoi oblasti. Naukovi chytannia, 119-122. [In Ukrainian].

Mysterud, A. (2014). Effects of selective harvesting on ungulate populations. In R. Putman, \& M. Apollonio (Eds.) Behaviour and management of European ungulates, (pp. 124-147). Dunbeath: Whittles Publishing. 
Podgórski, T., Baś, G., \& Jędrzejewska, B. (2013). Spatiotemporal behavioral plasticity of wild boar (Sus scrofa) under contrasting conditions of human pressure: primeval forest and metropolitan area. Journal of Mammalogy, 94(1), 109-119. https://doi.org/10.1644/12-MAMM-A-038.1

Smagol, V. N., \& Gavris, G. G. (2013). Zubr, Bison bonasus (Mammalia, Artiodactyla), v Ukraine: dinamika chislennosti, rasprostranenie, statcii i limitiruiushchie faktory. [The wisent Bison bonasus (Mammalia, Artiodactyla) in Ukraine: dynamics of population, area of distribution, habitat and limiting factors]. Kyiv: Veles. [In Russian].
Sönnichsen, L., Borowik, T., \& Podgórski, T. (2017). Survival rates and causes of mortality of roe deer Capreolus capreolus in a rural landscape, eastern Poland. Mammal Research, 62, 141-147. https://doi.org/10.1007/s13364-017-0308-2

Yevtushevskyi, M. N. (2009). Pliamystyi olen (Servus nippon hertulorum Swinhoe, 1864) v Ukraini ta za yii mezhamy. Kyiv: Vyd. dim "Eko-inform". [In Ukrainian].

Yevtushevskyi, M. N. (2012). Myslyvski tvaryny Ukrainy na voli ta $v$ volierakh. Cherkasy: Vertykal. [In Ukrainian].

Житомирский национальный агроэкологический университет, г. Житомир, Украина

\section{ВИДОВОЙ СОСТАВ И ДИНАМИКА ЧИСЛЕННОСТИ КОПЫТНЫХ АRTIODACTYLA} В ВОЛЬЕРАХ НА ТЕРРИТОРИИ ЖИТОМИРСКОЙ ОБЛАСТИ

Исследованы видовой состав и динамика численности копытных животных в вольерах Житомирской области. Площадь вольеров региона составляет 941,7 га. По состоянию на 2004 г. на территории области существовало 4 вольера общей площадью 374,2 га. На протяжении 2005-2009 гг. площадь вольеров колебалась от 117,2 га в 2005 г. до 178,2 га в 2009 г., в 2011 г. она уже составляла 576,7 га, а в 2016 г. - 715,2 га. В вольерах Житомирськой обл. содержат Cervus nippon, Cervus elaphus, Sus scrofa, Capreolus capreolus, Dama dama, Ovis ammon общей численностью 561 особь, которая за период 2004 2017 гг. возросла в 5 раз. В начале XXI в. на территории области существовало 4 вольера, в которых содержали 46 особей Cervus nippon и 75 особей Sus scrofa. До 2011 г. в вольерах региона содержали исключительно эти виды. В 2013 г. больше половины всего поголовья (52,4 \%) составлял Sus scrofa, за два года - в 2016 г. - его долевое участие составляло уже 40,0 \%, а в начале 2018 г. - всего 20,0 \%. Наиболее стойкой в хозяйствах региона остается популяция Cervus nippon, численность которой изменяется в пределах 40-56 особей. Установлено, что колебание численности Sus scrofa по годам очень существенно: от 15 особей (2005-2007 гг.) до 185 (2014 г.). Пользователи все чаще отдают преимущество Cervus elaphus, численность которого в вольерах за последние годы возросла до 166 особей. На протяжении 2012-2017 гг. численность Ovis ammon, Capreolus capreolus и Dama dama в хозяйствах области постепенно растет, как растет и численность самих хозяйств, где их содержат.

Ключевые слова: охотничье хозяйство; полувольное содержание; Sus scrofa; Cervus elaphus; Cervus nippon; Dama dama.

O. L. Kratiuk

Zhytomyr National Agroecological University, Zhytomyr, Ukraine

\section{SPECIES COMPOSITION AND NUMBER DYNAMICS OF ARTIODACTYLA UNGULATES IN ENCLOSURES IN THE TERRITORY OF ZHYTOMYR REGION}

Increasing the number and enrichment of the species composition of ungulates in hunting grounds by their breeding in semi-free conditions is relevant for the vast majority of hunting farms. The ungulate populations are characterized based on the materials of the State Statistics Service of Ukraine, the State Forest Resources Agency of Ukraine, and also hunting land users' projects of organization and development of hunting grounds of Zhytomyr Region. The total area of the enclosures is 941.7 ha. As of 2004, there were 4 enclosures in the territory of the region with the total area of 374.2 ha. During 2005-2009, the enclosures area ranged from 117.2 ha in 2005 to 178.2 ha in 2009. During 2011-2016, the gradual increase in the area of enclosures continued in the region, mainly due to private hunting farms. In 2011, the area of enclosures was 576.7 ha, and in 2016 it was 715.2 ha respectively. In 2017 , the main livestock of ungulates was 561 animals. Compared to 2004, the number of animals increased by almost 5 times. The ungulates are represented by Cervus nippon, Cervus elaphus, Sus scrofa, Capreolus capreolus, Dama dama, and Ovis ammon in the enclosures of Zhytomyr Region. Only Cervus nippon and Sus scrofa were kept in the enclosures of the region until 2011. At the beginning of the 21 st century there were 46 individuals of Cervus nippon and 75 individuals of Sus scrofa. Later Cervus elaphus, and the following year Ovis ammon and Dama dama were brought to the Kamia Plus Ltd. The population of Cervus nippon remains the most stable and predicted in the farms of the region. In recent years the number of species has ranged from 40 to 56 individuals. Sus scrofa population is supposed to be the most unpredictable nowadays. The variation of the number according to the years is very significant: from 15 individuals (2005-2007) to 185 individuals (2014). The users are gradually refusing to maintain a problem species and increasingly prefer Cervus elaphus, whose number in enclosures has increased to 166 individuals in recent years. Ovis ammon, Capreolus capreolus and Dama dama are considered to be quite promising for semi-free maintenance. Their number grows by natural increase within the enclosures. The place and role of enclosures in the modern hunting farms are reconsidered. The analysis performed confirms the unsystematic approach to managing hunting farms in most enterprises despite intensive biotechnical measures. Nevertheless, hunting farms in Zhytomyr Region have considerable potential in the development of enclosure farms, as evidenced by the increase in the number of enclosures, their area, number of animals, and the diversification of species composition

Keywords: hunting farm; semi-free maintenance; Sus scrofa; Cervus elaphus; Cervus nippon; Dama dama. 